\title{
The Efficiency of Google Classroom during Pandemic for Maritime English Learning in Akademi Maritim Nusantara
}

\author{
Yoana Gita Pradnya Lengari \\ Akademi Maritim Nusantara Cilacap \\ yoanalengari014@gmail.com
}

Diterima 02 September 2021, direvisi 24 September 2021, diterbitkan 06 Oktober 2021

\begin{abstract}
For almost 2 years, the educational system around the world has been influenced by the COVID-19 pandemic that leads to the shutting down of educational institutions including universities to control the spreading of the virus. This phenomenon coerces the government and also educational institutions to adapt their learning and teaching process. Along with various policies to handle the situation, the online learning system is suggested by Indonesian government as one of the solutions to facilitate distance learning. One of the methods to conduct distance learning is by using Google Classroom. This is a descriptive qualitative research with the fourth semester Engineering students of Akademi Maritim Nusantara as the subject. The key purpose of this research is to determine the efficiency of Google Classroom in Maritime English subject. The data are analyzed with Technology Acceptance Model (TAM). The efficiency of the platform is measured with the Ease of Access (PEU) and Perceived Usefulness (PU) towards Google Classroom Maritime English learning activity. The result of this study shows that most of the students are satisfied with Google Classroom that is applied in their class during COVID-19 pandemic in terms of the easiness of accessing their assignments, hence their efficiency as a learning tool can be considered appropriate.
\end{abstract}

Keywords : Google Classroom, Technology Acceptance Model, Distance Learning, Pandemic.

\begin{abstract}
Abstrak
Selama hampir 2 tahun, sistem pendidikan di seluruh dunia dipengaruhi oleh pandemi COVID-19 yang menyebabkan ditutupnya institusi pendidikan termasuk universitas untuk mengendalikan penyebaran virus. Fenomena ini memaksa pemerintah dan juga lembaga pendidikan untuk menyesuaikan proses belajar dan mengajar mereka. Seiring dengan berbagai kebijakan untuk menangani situasi tersebut, sistem pembelajaran online disarankan oleh pemerintah Indonesia sebagai salah satu solusi untuk memfasilitasi pembelajaran jarak jauh. Salah satu metode untuk melakukan pembelajaran jarak jauh adalah dengan menggunakan Google Classroom. Penelitian ini merupakan penelitian deskriptif kualitatif dengan subjek mahasiswa Teknik Akademi Maritim Nusantara semester IV. Tujuan utama dari penelitian ini adalah untuk mengetahui efisiensi Google Classroom dalam mata pelajaran Bahasa Inggris Maritim. Data dianalisis dengan Technology Acceptance Model (TAM). Efisiensi platform diukur dengan Penggunaan Individu (PEU) dan Persepsi Kemanfaatan (PU) terhadap aktivitas pembelajaran Bahasa Inggris Maritim Google Classroom. Hasil penelitian ini menunjukkan bahwa sebagian besar siswa puas dengan Google Classroom yang diterapkan di kelas mereka selama pandemi COVID-19 dalam hal kemudahan mengakses tugas mereka, sehingga efisiensi mereka sebagai alat pembelajaran dapat dianggap tepat.
\end{abstract}

Kata Kunci: Google Classroom, Technology Acceptance Model, Pembelajaran Jarak Jauh Pandemi. 


\section{Background}

The coronavirus disease or known as COVID-19 or the 2019 novel coronavirus is an infectious disease transmittable through droplets, or touching materials and surfaces that has been infected from patients with COVID-19 virus. (Bender, 2020).

The World Health Organization (WHO) has announced the outbreak of this infectious virus worldwide by March 2020. The increasing amount of cases that spread outside China in just a short period of time classify this phenomenon as a pandemic. According to Kelly (2011) pandemic is an outbreak that happens worldwide, that cross international borders and generally infecting a lot of people. The first confirmed cases of COVID-19 in Indonesia are on March 2, 2020. It has been escalated quickly to 4,07 million cases by August 29, 2021. Moreover, to deal with the circumstances, the government had approved large-scale social restriction run by local governments around Indonesia. This action is taken to control the fast spreading of the virus.

This social restriction affects all aspects of social, economical, and also educational for the people in this country. Since the early confirmation of the virus outbreak, home-based learning schemes had been implemented in Indonesia. It has been almost two years that this home-based learning policy first applied, and there are various methods used in executing the learning process. There are a variety of platforms that can be used to implement this method, such as Zoom, Whatsapp, Google Classroom or other online learning platforms.

One of the most popular platforms used around the world to support home-based learning is Google Classroom. Google Classroom is a learning platform initiated by Google to facilitate any educational range which intended to assist in the organization of paperless assignments (Sukmawati et al, 2019). In 2014, Google Apps for Education launched Google Classroom to assist educator to be able to generate assignments swiftly, communicate with the students easily, and provide feedback efficiently (Wida et al, 2016).

In this paper, Technology Acceptance Model (TMA) is applied to analyze the efficiency of Google Classroom in Maritime English learning for fourth semester engineering students in Akademi Maritim Nusantara. The results and findings of the study are then explained and summarized. TAM is a simple and accurate outline and has been adopted widely to illustrate user acceptance of information technology. TAM shows how the individual's significant beliefs (perceived usefulness and perceived ease of use), predict the user's behavioral intention to utilize a given system, and, in turn, predicts their actual system use.

In the case of distance learning, particularly online learning, there are two reasons why people accept or reject the purpose of information technology. First, people are likely to utilize or not the information technology because of the consideration that this technology can complicate them in improving their task, this item is described as Perceived Usefulness (PU). Next, even though prospective consumers consider that this information technology is helpful for them, however they also believe that the technology is too complicated to make use of, this variable is referred to as perceived Ease of Use (PEU).

There are several researches that utilize the Technology Acceptance Model in their studies. Handayani and Harsono (2016) study the effect of the TAM on computerized land activities. The research resulted in the perceived of usefulness of the technology, the attitude towards technology usage, and the intention to use technology. A research by Yea-Ru Tsai (2014) in applying the TAM to explore the effect of a Course Management System (CMS)-Assisted EFL writing instruction suggested that most of the students demonstrate positive learning outcomes, indicating that the model contributed to the effectiveness of English Writing lesson. The factors that influence the performance improvement in writing lesson are technical support, perceived usefulness, perceived ease of use, and attitude.

\section{Research Method}

The populations in this research are fourth semester students in engineering program that signed up on Maritime English subject. Random sampling had been applied in selecting the sample.

In order to put together an instrument for the questionnaire, this study employs the internet 
self-efficacy scale by Eastin and Larose as a reference. To measure each entry, a nominal scale of one to five which range from 1 (strongly disagree) to 5 (strongly agree).

The Technology Acceptance Model (TAM) method is applied in this study. TAM was developed to suggest a behavioral theory in the use of computer technology (Davis, 1989) based on the Theory of Reasoned Action (TRA) (Fishbein and Ajzen, 1975). Technology Acceptance Model (TAM) use to predict and explain users of technology will recognize and use technology to support their work. . This model is developed from the psychological theory to explain the behavior of information technology users based on belief, intention, attitude, and user behavior relationships. This theory formulates a model of a person's behavior as a function of behavioral goals (Davis, 1989).

The theory proposes that the students' behavioral intention in using Google Classroom is established by two key viewpoints. These two points are perceived usefulness (PU) and perceived ease of use (PEU) (Venktatesh and Davis, 2000). PU refers to the point in which a person consider that using a particular system would improve their work performance, whereas PEU refers to the point in which a person consider that making use of a particular system would be free from efforts.

This survey involved 49 students from 2 classes of Maritime English subject in engineering program at Akademi Maritim Nusantara Cilacap.

\section{Result and Findings}

The Likert type question was used to respond the issue on how frequent students accessed the internet. It was given in the questionnaire to determine the use of information and communication technology stage of the respondents. The chart in Figure 1 showed that most of the respondents used internet many times a day. This could mean that the respondents were familiar, accustomed to, and knowledgeable in terms of the information technology usage in their everyday life.

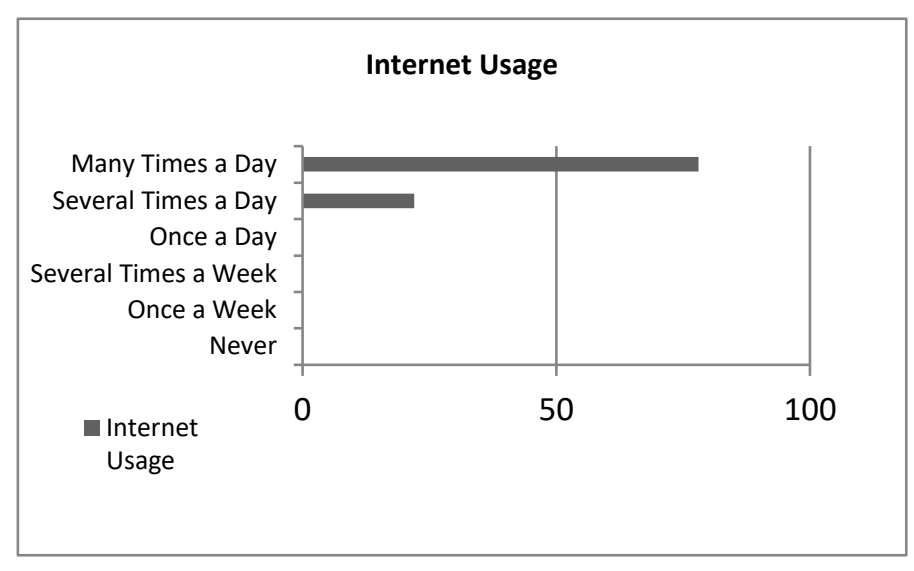

Figure 1. Internet Usage Average among Students

Table 1.

Mean Value for the Ease of Access

\begin{tabular}{|c|l|c|}
\hline Feature & \multicolumn{1}{|c|}{ Component } & Mean \\
\hline \multirow{4}{*}{$\begin{array}{c}\text { Ease of } \\
\text { Access }\end{array}$} & \begin{tabular}{l} 
Easy sign on to the platform \\
\cline { 2 - 3 }
\end{tabular} & $\begin{array}{l}\text { Accessing Subject resources and } \\
\text { material }\end{array}$ \\
\cline { 2 - 3 } & $\begin{array}{l}\text { Sending, Receiving, \& Submitting } \\
\text { Assignments }\end{array}$ & 4.37 \\
\cline { 2 - 3 } & Easy navigation on the Application & 4.62 \\
\cline { 2 - 3 } & Easy to comprehend the Application & 4.35 \\
\hline
\end{tabular}

Table 1 illustrates the mean value for the ease of access in Google Classroom for Maritime English lesson. It showed that the highest mean on the table of Ease of Access is the sending, receiving and submitting assignments factor with 4.62 mean value. This means that the respondents strongly agree that the use of Google Classroom help the students to complete their assignment. Whereas, the lowest mean on the table of Ease of Access is the Easy to Understand the Application component with 4.26 mean value. This means that the students are more likely to have difficulty in understanding the Google Classroom program. The lecturer should pay attention in assisting and helping the students with the information on the subject of Google Classroom program in order to make the students recognize more about the program.

The average mean value on Table 1 which rated from 4.17 to 4.78 out of 5 , showed that the students were mostly had no difficulty in accessing Google Classroom, hence the 
efficiency in utilizing this platform for distance learning in terms of ease of access was considered high.

Table 2.

Mean Value for the Perceived Usefulness

\begin{tabular}{|c|l|c|}
\hline Feature & \multicolumn{1}{|c|}{ Component } & Mean \\
\hline \multirow{4}{*}{$\begin{array}{c}\text { Perceived } \\
\text { Usefulnes } \\
\text { s }\end{array}$} & Excellent learning quality & 4.25 \\
\cline { 2 - 3 } & $\begin{array}{l}\text { An excellent medium for social contact } \\
\text { Aiding to on time assignment } \\
\text { submitting }\end{array}$ & 4.17 \\
\cline { 2 - 3 } & $\begin{array}{l}\text { Useful feedback provided by the } \\
\text { lecturer }\end{array}$ & 4.78 \\
\cline { 2 - 3 } & $\begin{array}{l}\text { Good grading system for monitoring } \\
\text { learning performance }\end{array}$ & 4.53 \\
\hline
\end{tabular}

As we could observe in Table 2 for the Perceived Usefulness in using Google Classroom for Maritime English Lesson, it showed that the highest mean on the table of perceived usefulness, the respondents consider that the use of Google Classroom facilitates them in accomplishing their assignments. The Google Classroom aiding to send, received, and submitted their assignment has the highest mean value of 4.78 . With the deadline feature in the program, it helps the students to remember and finish their assignments on time. Subsequently, the lowest mean value can be seen in the medium of social interaction factor with 4.17 mean value. This result indicates that the respondents consider Google Classroom platform have not facilitate their needs in social interaction between students and lecturer or students and other students.

The average mean value on Table 2 which rated from 4.26 to 4.62 out of 5 showed that the most of the students found that the Google Classroom platform was useful in aiding them with the lesson materials; hence the efficiency in utilizing this platform for distance learning in terms of perceived usefulness was also considered high.

\section{Conclusion}

The result of the study determined that, in general, the fourth semester students of engineering program who sign up for Maritime English subject were pleased with Google Classroom usage in their learning activity and is efficient during the COVID-19 pandemic. The efficiency in terms of ease of access and perceived usefulness showed high mean values that meant the students found that Google Classroom was easy to use and was useful in assisting them in learning the materials.

The research attempt shows that observations, studies, and investigations of student learning plan that leads to a better student's satisfaction on method of learning will continue to grow. This approach, will contribute to teachers to maintain curriculums that allow students to do well in online learning atmosphere. It is appropriate that Google Classroom should be integrated into the lessons that are given in the engineering program, not only because it is a useful learning program to be applied in time of pandemic, but also enhance the skill of technological development in the future.

\section{Bibliography}

[1] Bender, L. (2020). Key Messages and Actions for COVID-19 Prevention and Control in Schools. Retrieved from https://www.unicef.org/romania/documents /key-messages-and-actions-covid-19prevention-and-control-schools

[2] Kelly, Heath.(2011). The classical definition of a pandemic is not elusive." Bulletin of the World Health Organization, vol. 89, no. 7, July 2011.

[3] Sukmawati, S., and Nensia, N. 2019. The Role of Google Classroom in ELT. International Journal for Educational and Vocational Studies, 1 (2), 142-145.

[4] Davis FD, Bagozzi RP, Warshaw PR. User Acceptance of Computer Technology: a Comparison of Two Theoretical Models. Management Science Aug 1989. 1989;35(8):982-1003.

[5] Handayani, Wahyu Prabawati Putri and Mugi Harsono. 2016. Aplikasi Technology Acceptance Model (TAM) pada Komputerisasi Kegiatan Pertanahan. Jurnal Economia Vol. 12 No.1, 13-22.

[6] Tsai, Yea-Ru. 2014. Applying the Technology Acceptance Model (TAM) to Explore the Effects of a Course Management System (CMS)-Assisted EFL Writing Instruction. Computer Assisted Language Instruction Consortium. Vol 32.1 2015 , 53-171. https://www.jstor.org/stable/calicojournal.3 $\underline{2.1 .153}$ 
[7] Wida, Putu Ayu Mira Witriyanti, Ni Nyoman Kerti Yasa dan I Putu Gde Sukaatmadja. 2016. Aplikasi Model TAM (Technology Acceptance Model) pada Perilaku Pengguna Instagram. Jurnal Ilmu Manajemen (JUIMA). Vol 6 No 2 (2016). http://ojs.unmas.ac.id.

[8] F. D. F. Davis, "Perceived usefulness, perceived ease of use, and user acceptance of information technology," MIS Q., vol. 13, no. 3, pp. 319-340, 1989. https://doi.org/10.2307/

[9] Fishbein, M. \& Ajzen, "Belief, attitude, attitude, intention and behavior: An introduction to theory of research," Reading, MA Addison-Wesley AddisonWesley, p. 578, 1975.

[10] Venktatesh, Viswanath. and Fred D. Davis. 2000. A Theoretical Extension Of The Technology Acceptance Model: Four Longitudinal Field Studies. Journal Management Science. Vol. 46 No. 2 (2000), pp. 186-204.

[11] Eastin, M. S., and LaRose, R. Internet selfefficacy and the psychology of the digital divide. J. Comput. Commun, 2000, 6(1). 